\title{
EXPLORING CONSUMERS' PROPENSITY FOR ONLINE SHOPPING IN A DEVELOPING COUNTRY: A DEMOGRAPHIC PERSPECTIVE
}

\author{
Michael Adu KWARTENG ${ }^{1}$, Michal PILÍK ${ }^{1}$
}

\begin{abstract}
:
The advent of the Internet continues to open new frontiers in digital marketing. One visible impact of the Internet in marketing has been the growing increase in online transactions which profits marketers and seemingly satisfies customers. However, in developing countries, the potential of online shopping has not been fully explored, and in some cases, are just non- existent. Lack of online infrastructure has often been attributed to the slower growth in online transactions in Africa, however, the customers' preparedness and inclination to use the service is ignored. .Against this backdrop, this study seeks to analyze consumers' propensity to engage in online transactions with a focus on demographic attributes such as age, gender and education. Using customers in Ghana as a case study, key reasons as well as the demographics that fancy online transactions are revealed. The results indicate that delivery problems, poor internet connection, privacy and security issues are some of the reasons preventing customers to shop online
\end{abstract}

\section{KEYWORDS:}

E-Commerce, On-Line Shopping, Consumer Buying Behavior, Ghana

\section{INTRODUCTION}

One of the most visible impacts on global marketing has been online shopping (Quelch and Klein,1996). Its introduction has in many ways significantly reduced transactions in the traditional brick and mortar sector. A report from Nielsen Global Consumer Confidence Survey of 2010 on internet shopping habits of customers, revealed a tremendous increase in the shopping habits of customers from 45\% to almost 85\% from 2011 to 2015 (Nielson, 2015). The report further indicated that a chunk of internet users are located in countries with the high internet penetration. New Zealand tops the Asia Pacific region with 95\% share of internet penetration; Finland recorded the highest internet penetration with 97\% share in European region; Argentina leads with 75\% share in Latin America; Middle east and some part's of Africa saw United Arab Emirates(UAE) recording 96\% of the share of internet penetration; Canada and the United states of America(USA) as well as the North American continent recorded $97 \%$ and $87 \%$ respectively with Ghana leading Sub Saharan countries of $99 \%$ of mobile penetration ahead of its sister countries Nigeria and Kenya.(Nielsen company,2015)

\footnotetext{
${ }^{1}$ Faculty of Management and Economics, Tomas Bata University in Zlín, Mostní 5139, 76001

Czech Republic
} 
As evidenced from the survey, the African continent in general has been recognized as a very weak internet penetration region with lower eCommerce business transactions and in particular the sub Saharan regions. Accordingly, (Naberesah et al., 2014) investigated the factors that inhibit online buying in two emerging countries in the Western part of Africa, namely Nigeria and Ghana to ascertain the readiness of customer's online buying attitude. Their results revealed many factors such as trust, internet connectivity among others as reasons for customers' inability to shop online, in spite of the perceived benefits accruable to customers. Quarshie and Ami-Narh (2012) reiterated in their findings that apart from the massive mobile penetration in Ghana in this recent times, $46.6 \%, 33.75 \%$ engage in online transactions specifically for educational purpose and news respectively, whiles $6.35 \%$ representing the entire populace make use of the internet for transaction. The area of eCommerce and online transactions is entirely new situation in the African sub region. Despite the Western world in deliberating on topics related to consumer's attitudes and perceptions and also factors influencing their purchasing behaviors in the area of eCommerce and online transactions, much has not been done to delving into consumers' willingness to embark on online buying within the African continent.As a matter of fact, these teething problems create a research space to review efforts as well as the rate of online buying behavior of customers in Africa as a whole, and Ghana in particular being the focus of the research. For that reason, this study is aimed at probing into the tendency for online shopping relations, taking cognizance of some demographic factors in Ghana. The findings of this research will serve as a bait for both Multinationals and international corporations who are bent on entering the African continent with ebusiness ideologies.

This exploratory study is further outlined as follows. The next section is captured with related literature and hypotheses development. The third part is centered on the research methods used for the study whilst remaining section presents the research findings. We conclude this paper by offering a detailed discussion, study's implications, limitations, future research proposal followed by final remarks.

\section{THEORETICAL BACKGROUND}

\subsection{Consumer Behavior and online Shopping}

With the upsurge of internet penetration within the entire marketing arena in the past few decades, Consumers have sought the need to embark on online transactions. Online transactions or shopping is defined as the way and manner customers make use of the internet in search of information relating to a particular product, and to make trade-offs with the intensions of finalizing a purchase transaction (Alturkestani, 2004). Thus, how, internet users in general make a retail purchase with the aid of internet connectivity (Swinyard and Smith, 2003). The internet as an influence on consumer behavior cannot be overlooked. Numerous studies have provided empirical evidence indicating that customers who shop online are more likely to behave differently in the overall shopping decision as compared to those who shop through the conventional brick and mortar style. (Donthu and Garcia, 1999; Soopramamien and Robertson, 2007).

In line with the inclination for consumers to purchase online coupled with the rate at which consumers are keen on purchasing online, previous studies have measured these scenarios in different contexts. For instance, Lian and Lin (2008) in their studies pointed out that, the extent of consumer's passion to purchase online stems from the fact that customers are more likely to return to their respective websites of purchase within the next three months or during the year from the initial purchase, hence increasing their online purchase. Again, convenience is measured as and when customers make use of the internet to make purchases. Online shoppers stand the chance of enjoying multiple forms of convenience in the form of less physical effort, flexibility in terms of shopping, lenience in responding to promotions as well as advertisement, and finally accompanied 
by some user friendly websites (Soopramamien and Robertson, 2007, Suki et al., 2008).Over again, online shoppers intend to recommend others on particular websites with discounts on sales and other information on some particular websites which induce consumers' willingness to purchase online (Domina et al, 2012)

Conversely, previous literatures have elaborated that customers who embark on online purchasing are less likely to inhibit the anxiety in terms of risk of financial cost (Alfred et al., 2006). Doolin et al. (2007) also reiterated that customers in the fold of online purchasing have a higher propensity of risk leniency. Similarly, it was revealed by (Donthu and Garcia, 1999. Brashear et al., 2009) that such customers are less likely to be risk averse more than the traditional brick and mortar customers. Additionally, consumers are keen on the terms used in purchasing through the World Wide Web (www), (Li and Zhang (2002).

On a broader perspective, literature has been reviewed on the concept and measures of consumer behavior within the domain of online purchasing. Taking grasp of the attitudes and tendency for online shopping, the researcher considered a number of factors in the literature ranging from perceived risk in the internet world of shopping, consumer behavior and convenience, satisfaction and predicaments from the online shopping circumstances. This study is centered on consumer behavior of online shopping from a developing economy, reflecting on the tendency for customers to shop through online.

\subsection{Demographic interplay of Online Shopping Behavior}

Demographic attributes of respondents towards online shopping has been studied extensively in internet marketing in general and an online purchasing behavior in particular. Accordingly, previous literatures have outlined the association between demographic factors that are linked with online buying from countries to countries. Some of these studies were focused on gender, income, age, and education. Table 1. below presents a review of the most important results of such studies

Table 1: Literature support of some selected demographic factors

\begin{tabular}{|l|l|}
\hline Demographic factor(s) & Literature support of the selected demographic factors \\
\hline Gender & $\begin{array}{l}\text { (M Gupta, 2010; Stafford et al. 2004; Burke, 2002; Hague } \\
\text { and Mahmoud, 2007; Susskind, 2004; Doolin et al. 2005; } \\
\text { Bartel-Sheehan, 1999) as cited by Saleh, (2015)Raman_et } \\
\text { al,2015; Kumar et al,2015; Rigas et al,2015; Rose et } \\
\text { al,2014; Shuyang et al, 2014; Martín et al,2011, Nathan et } \\
\text { al,2009,Shen et al,2007, Sakalauskas et al, 2005, } \\
\text { Hansen,2005; Garbarino et al,2004; Ellen and Michal ,2004; } \\
\text { Marie-Odile et al,2010 }\end{array}$ \\
\hline Age & $\begin{array}{l}\text { Román et al, 2014, Brecht et al, 2010, Kim and Park, } \\
\text { 2005,Bouzaabia et al,2016;Desai et al,2015; Román,_et al, } \\
\text { 2014, Mazur et al, 2012; Niu et al,2014;Kumar et al,2015; } \\
\text { Hart, M.,2008;Xiang and David,2006; Rajarshi et al,2016; } \\
\text { Jiunn-Woei and David,2014; Syed, H,2012 }\end{array}$ \\
\hline Education & $\begin{array}{l}\text { Beldona, et al,2011; ,2007; Hansen, T.,2005; Sharma and } \\
\text { Sitlani,2013;Román and Riquelme,2014 ,Raman and } \\
\text { Pramod,2015; Jianwei and Kevin;2014, Luca et al,2016, } \\
\text { Xiang and David,2006; Syed, H,2012; Soyeon et al,1991 }\end{array}$ \\
\hline
\end{tabular}

Source: ( Own research) 


\section{RESEARCH QUESTIONS AND HYPOTHESIS}

Taking into account the findings of the previous studies on consumers' willingness for online shopping. The following research questions were outlined in the study. Borrowing from the words of Maceviciute (2007), cited from Alison Jane Pickard, research questions are stated to propel a research design into specific study. In this research, the under listed research questions are proposed in tandem with the objective of the paper to guide the study:

RQ1: What is the significant relationship between age and gender at how often consumers use internet/online channel for shopping.?

RQ2: Does age have a relationship with channel(s) consumers use to check for the availability of new products.?

RQ3: Does education and age have a relationship with the usage of internet shopping?

\subsection{Hypothesis Development}

On the basis of the above discussions and previous empirical findings towards demographic interplay of respondents, we stated the following hypotheses prior to the research.

H1: There are no relationships between consumers age and gender on how often the internet is used for shopping.

H2: There are no relationships between consumers age and gender on checking availability of new product

H3:There are no relationship between education and age for consumers on the usage of internet for shopping

\section{METHODOLOGY}

\subsection{Sample and procedure}

This study was conducted on the notion of probability sampling. Hence, the random sampling technique was used in the study, indicating that each member of the population has an equal chance to be sampled for the study. In the gist to ascertain a deeper and accurate results of a larger population under study, pertaining to a particular research, it demands the use of simple random sampling (Liu et al,2004). Data collection of our work was prepared in the form of a questionnaire with the help of Google Docs application software. A questionnaire has been used because it is a well-established tool within social science research that aids in acquiring information on the participants' social characteristics, present and past behavior, standards of behavior or attitudes and beliefs and also reasons for action with respect to the topic under investigation (Bulmer, 2004). The questionnaire was prepared entirely on the bases of close ended type with seventeen questions. The period of data collection was between December 2015 to February 2016.

For the sake of the study, the questionnaire was sent through online for respondents to fill. In an attempt to increase the response rate for the study, questionnaires were printed as a hard copy format in Ghana through emails by some resource correspondents to aid in the research. 602 questionnaires were made available for a sample of the targeted population in the capital of Ghana and the second largest city in Ghana, namely Accra and Kumasi respectively. Out of 602 questionnaires that were issued to the respondents, a total of 563 were received, of which 52 of these responses were invalid and hence were omitted from our analyses. However, 511 valid questionnaires were accurately considered for our analyses, demonstrating approximately $88 \%$ of the entire questionnaires to the respondents. Adindoft XL starts(2014) software was used for our 
evaluation.Table 2. Below shows the frequencies and percentages for some demographic factors of our sample. These consist of gender, age, education and employment level of respondents.

The demographic profile of the respondents' frequencies and percentages are summarized in Table 2. Of the respondents ,there were more female (267) representing ( $52.3 \%)$ ahead of males of (244) with $(47.7 \%)$. The majority of the respondents came from the age group between $18-29$, (326) which represents $63.9 \%$ out of the total. In terms of education, most respondents were Bachelors or University graduates (293). That is with the first degree representing $57.9 \%$ of the total, followed by those who completed postgraduate level, in other words, with masters and $\mathrm{PhD}$ studies.Approximately half of the respondents had a job (222) with $43.4 \%$ whiles the other half had no job (204) with $44 \%$ as of the time of the research.

The dependence of the given variables, that is the dependence of the aforementioned demographics and the propensity of online shopping was tested by using Pearson's chi-square test at a significance level of $\alpha=0.05$. On the foundations of the interdependence of achieving value of the chi-square statistics (x2) as well as the set of data values, it has been ascertained whether the hypothesis set prior to the research should have been accepted or rejected. It must be stated that in most of our assessment of hypotheses, we made use of descriptive statistics with percentage calculations.

Table 2. Socio-demographic profile of respondents

\begin{tabular}{|l|l|c|c|}
\hline \multicolumn{2}{|l|}{$\begin{array}{l}\text { Demographic considerations of the } \\
\text { respondents }\end{array}$} & Frequencies & Percentages \% \\
\hline \multirow{2}{*}{ Gender } & Male & 244 & 47.7 \\
\cline { 2 - 4 } & Female & 267 & 52.3 \\
\hline \multirow{4}{*}{ Age } & $18-29$ years & 326 & 63.9 \\
\cline { 2 - 4 } & $30-50$ years & 168 & 32.9 \\
\cline { 2 - 4 } & 51-over years & 17 & 3.2 \\
\hline \multirow{5}{*}{ Education } & High school & 14 & 2.7 \\
\cline { 2 - 4 } & Bachelors & 293 & 57.9 \\
\cline { 2 - 4 } & Postgraduate & 204 & 39.4 \\
\hline \multirow{3}{*}{ Employment level } & Employed & 222 & 43.4 \\
\cline { 2 - 4 } & Unemployed & 225 & 44.0 \\
\cline { 2 - 4 } & Other & 64 & 12.5 \\
\hline
\end{tabular}

(Source: Own Research)

\section{FINDINGS}

Survey results are tabulated below: the relationship between how consumers use the internet for shopping with its corresponding age and gender. (Table 3 )

Table 3: Shows the statistical testing for Age and Gender on how often consumers make use of the internet for shopping. As the computed $p$ value of both variables (Age $=0.3424$, Gender $=0.6358$ ) are greater than the alpha level $(\alpha=0.005)$, it can be deduced that the null hypothesis stated above cannot be rejected, giving the risk by $34.24 \%$ and $68.58 \%$ separately of age and gender to reject the null hypothesis (HO). Furthermore, the overall age in percentage accompanied by how often consumers are enticed with the usage of internet for shopping daily, Once per week, twice per month and other means stood at $(28.57 \%, 19.57 \%, 36.97 \%, 14.87 \%)$ respectively evidenced from the statistical analyses. Again,between the ages of (18-29 years) it was proven that $37.42 \%$ of the respondents use the internet Twice per month with the ages between 30-50 years using the internet 
twice per month, followed by those respondents whose ages are 50 and beyond also making use of Once per week with the percentage of $35.29 \%$ ahead of the other dependent variables.

Conversely, it can be seen from the Table (3) above that gender of our respondents had entirely different suggestions by the respondents after testing our results statistically. Females recorded the highest percentage of regularly using the internet for shopping with $43.45 \%$, slightly above the percentage accrued from their male respondents which also stood at $41.39 \%$, with the use of the internet twice per month.

Table 3: Internet Usage for shopping

\begin{tabular}{|c|c|c|c|c|c|c|}
\hline & \multicolumn{4}{|c|}{ Age } & \multicolumn{2}{|c|}{ Gender } \\
\hline & Total & $\begin{array}{l}18-29 \\
\text { years }\end{array}$ & $\begin{array}{l}30-50 \\
\text { years }\end{array}$ & $\begin{array}{l}\text { 51-over } \\
\text { years }\end{array}$ & Male & Female \\
\hline Daily & 28.57 & 28.53 & 29.18 & 23.53 & 19.26 & 22.10 \\
\hline Once per week & 19.57 & 17.18 & 22.62 & 35.29 & 29.10 & 24.34 \\
\hline Twice per month & 36.97 & 37.42 & 36.90 & 29.41 & 41.39 & 43.45 \\
\hline Other & 14.87 & 16.87 & 11.31 & 11.76 & 10.25 & 10.11 \\
\hline Critical values of $x 2$ & \multicolumn{4}{|c|}{12.5916} & \multicolumn{2}{|c|}{7.8147} \\
\hline Calculated values of $x 2$ & \multicolumn{4}{|c|}{6.7723} & \multicolumn{2}{|c|}{1.7052} \\
\hline DF & \multicolumn{4}{|c|}{6} & \multicolumn{2}{|c|}{3} \\
\hline P value & \multicolumn{4}{|c|}{0.3424} & \multicolumn{2}{|c|}{0.6358} \\
\hline
\end{tabular}

(Source: Own Research)

Table 4. Shows the statistical testing for Age and Gender on what consumers use to check the availability of new products. As the computed $p$ value of both variables (Age $=0.0016$, Gender $=0$. 0065 are lower than the alpha level $(\alpha=0.005)$, it can be construed that the null hypothesis can be rejected, giving the risk by $0.16 \%$ and $0.65 \%$ to reject the null hypothesis (HO). Besides, the overall age in percentage complemented with what consumers use to check the availability of new product on the market such as the use of online,Printed media, traditional brick and mortar or any other means ranges from (30-50) with $70.24 \%$ followed by (18-29), also with the traditional brick and mortar style hooking at $59.86 \%$. Comparatively, apart from the traditional brick and mortar evaluation by our statistical inferences, it can be seen that customers or the respondents are keen or making use of the Online means in checking the availability of new products as already envisaged.Print media and other means by respondent, however recorded least in percentage so far as our statistical evaluation was concerned.

On the contrary, it can be tracked from the table 7 above that gender of our respondents had different proposition so far as checking availability of new products is concerned.Males recorded highest percentage of checking availability of new products with the variables such as Online,Printed media,Traditional or any other means representing 45.90\%(Males) slightly above the percentage accrued from their Female respondents which also stood at $45.32 \%$, with both of them using traditional brick and mortar in checking availability of new products in the market.Again,Online followed suit with respect in checking availability of new products with $35.25 \%, 34.46 \%$ for male and female respectively. 
Table 4: Channels used for checking availability of new products

\begin{tabular}{|c|c|c|c|c|c|c|}
\hline & \multicolumn{4}{|c|}{ Age } & \multicolumn{2}{|c|}{ Gender } \\
\hline & Total & $\begin{array}{l}18-29 \\
\text { years }\end{array}$ & $\begin{array}{l}30-50 \\
\text { years }\end{array}$ & $\begin{array}{l}\text { 51-over } \\
\text { years }\end{array}$ & Male & Female \\
\hline Online & 20.74 & 23.39 & 17.26 & 23.53 & 35.25 & 34.46 \\
\hline Printed Media & 14.87 & 17.79 & 8.33 & 23.53 & 15.98 & 10.49 \\
\hline $\begin{array}{l}\text { Traditional channel } \\
\text { (shop) }\end{array}$ & 59.89 & 55.83 & 70.24 & 35.29 & 45.90 & 45.32 \\
\hline Other & 4.50 & 3.9 & 4.17 & 17.64 & 2.87 & 9.74 \\
\hline Critical values of $x 2$ & \multicolumn{4}{|c|}{12.5916} & \multicolumn{2}{|c|}{7.8147} \\
\hline Calculated values of $x 2$ & \multicolumn{4}{|c|}{21.4066} & \multicolumn{2}{|c|}{12.2849} \\
\hline DF & \multicolumn{4}{|c|}{6} & \multicolumn{2}{|c|}{3} \\
\hline P value & \multicolumn{4}{|c|}{0.0016} & \multicolumn{2}{|c|}{0.0065} \\
\hline
\end{tabular}

(Source: Own Research)

Table 5. Shows the statistical testing for Age and Education on how consumers advocate the use of the internet for shopping.It is evidenced from our statistical analyses that the computed $p$ value of both variables $(\mathrm{Age}=0.0001$, Education $=0.1725)$ recorded different $\mathrm{P}$ values implying that there is a diverse interpretation of both variables under study. Age on the other hand,has its $p$ value smaller than the significance level set before the evaluation $(\alpha=0.005)$, whiles education has a higher $p$ value and hence it can be deduced that the null hypothesis cannot be rejected for age whiles education can be rejected However, the overall age in percentage accompanied with the support for internet shopping was $49.31 \%$ for as against No respondents recording $50.68 \%$.Yet,between the ages of (18-29 years) it was proven that $60.74 \%$ of the respondents from our sample are advocating for the use of the online shopping with ages (50-over years ) $70.59 \%$ of the respondents also not in aggrement with the use of internet for shopping. Unfortunately,(30-50 years) also supported the assertion of not making use of the internet for shopping..

Contrariwise, it can be seen from the table 6 . Again, though, that above that educational level of our respondents had entirely different suggestions, even inasmuch as our null hypothesis created cannot be rejected. In the percentage calculations from our statistics, it was ascertained that High school,Bachelors, and Postgraduate levels of our respondents all advocated for the use of internet for shopping,recording 57.14\%, 71.01, 76.96 respectively.Post graduate level of our respondents with the bachelor levels on the recorded few disagreement with the usage of internet for shopping $(27.99 \%, 23.04 \%)$

Table 5: Consumers Advocate for the use of internet shopping

\begin{tabular}{|c|c|c|c|c|c|c|c|}
\hline & \multicolumn{4}{|c|}{ Age } & \multicolumn{3}{|c|}{ Education } \\
\hline & $\begin{array}{l}\text { Tota } \\
\text { l }\end{array}$ & $\begin{array}{l}18-29 \\
\text { years }\end{array}$ & $\begin{array}{l}30-50 \\
\text { years }\end{array}$ & $\begin{array}{l}\text { 51-over } \\
\text { years }\end{array}$ & $\begin{array}{l}\text { High } \\
\text { schoo } \\
\text { l }\end{array}$ & $\begin{array}{l}\text { Bachelo } \\
\text { r }\end{array}$ & $\begin{array}{l}\text { Post } \\
\text { Gradu } \\
\text { ate }\end{array}$ \\
\hline Yes & $\begin{array}{c}49.3 \\
1\end{array}$ & 60.74 & 29.17 & 29.41 & 57.14 & 72.01 & 76.96 \\
\hline No & $\begin{array}{c}50.6 \\
8\end{array}$ & 39.26 & 70.83 & 70.59 & 42.86 & 27.99 & 23.04 \\
\hline Critical values of $x 2$ & \multicolumn{4}{|c|}{5.9915} & \multicolumn{3}{|c|}{5.9915} \\
\hline Calculated values of $\times 2$ & \multicolumn{4}{|c|}{46.9926} & \multicolumn{3}{|c|}{3.5151} \\
\hline DF & \multicolumn{4}{|c|}{2} & \multicolumn{3}{|c|}{2} \\
\hline P value & \multicolumn{4}{|c|}{0.0001} & \multicolumn{3}{|c|}{0.1725} \\
\hline
\end{tabular}

(Source:Own Research)

4.1 Reasons for not advocating for online shopping 
The figure (1) illustrates the main reason why customers are not keen on making use of the internet for online shopping in Ghana. Customers were much concerned about delivery problem,accounting for $(55 \%)$ of our respondents' response, should they buy from the internet and hence creating fear and panic in them.Another concern was the slow and poor internet connections in Ghana.The third main reason was that most of our respondents were much particular about security and privacy issues when using the internet in shopping, amidst fear and panic to engage in that means compared to walking straight to the market for purchasing.Almost (20\%) of the respondent's was of the view about security and private issues and hence preferred the real life shopping experience.Out of our respondents who undertook our survey, only few attributed their fear to the internet cost that might crop up in the gist to purchase online, that is approximately (10\%) whiles the remaining percentage was addressed to a reason best known to respondents, representing a negligible responses attained from the survey. However, in practice this assertion might differ, for individuals having a diverse views with respect to the problem of fears in purchasing through the internet or online.

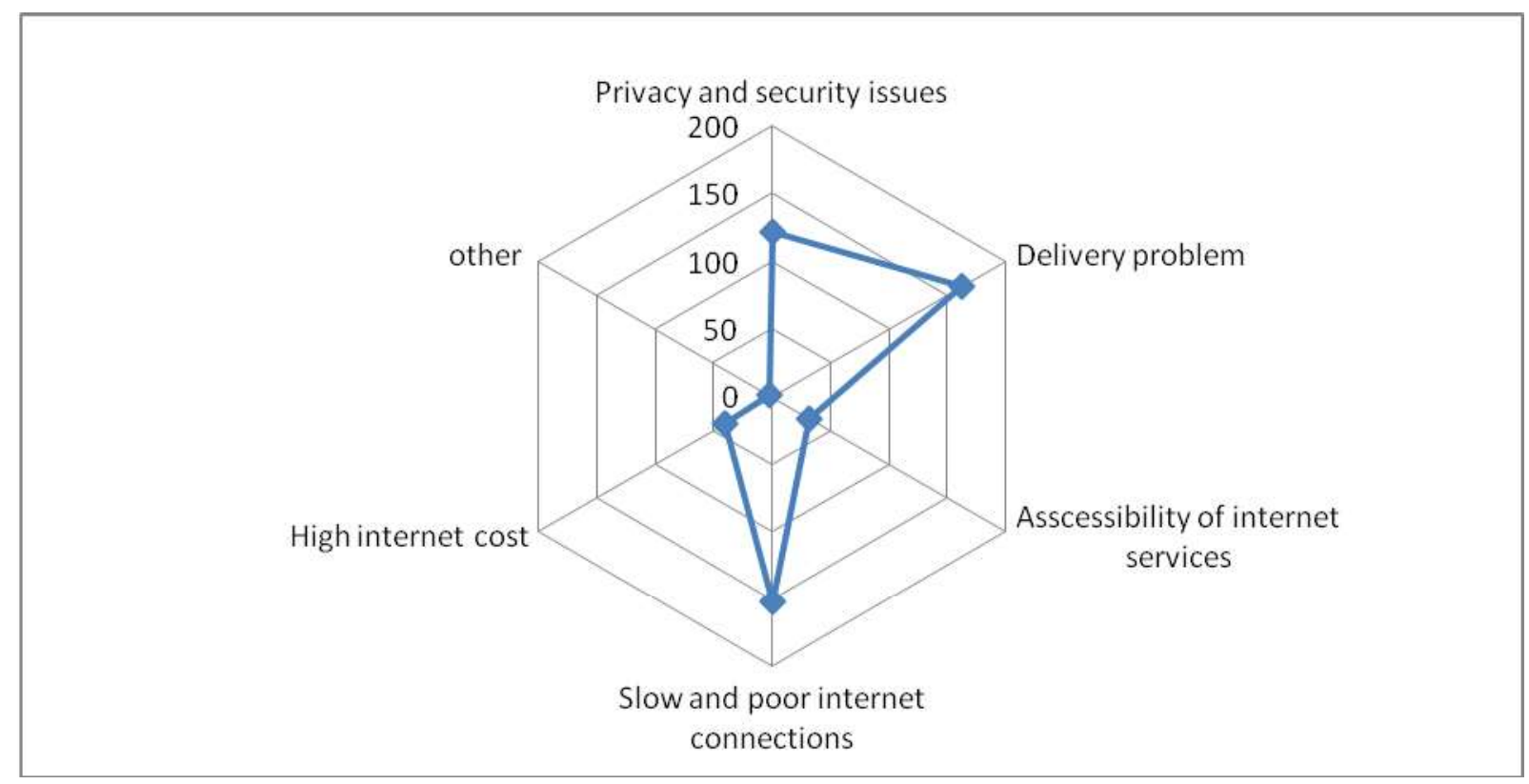

Figure 1: Reasons for not supporting the use of online shopping by respondents in consummate numbers: (Source Own Survey)

\subsection{Customer preference for online shopping}

Among our respondents who were sampled for our study,more than (50\%) preferred using the internet for shopping because of ease and faster access of their required products.In other words,flexibility and convenience attained by them should they shop through online or with the internet.The reasons that most of our respondents quoted for purchasing via the internet centered on the proposition that the internet provides instant services ,even at dawn and anytime one feels to make purchase.Infact more than (30\%) of our respondents supported the online shopping agenda because of ' $24 / 7$ ' connectivity unlike the traditional brick and mortar shopping that has a time span for assessing a product or a commodity.As it can be seen from the figure above,comparison of prices before initiation was one of the main disposition that was addressed through our evaluation and hence a pertinent reason for admiration of our respondents'. Lately, there are different kinds of brands as well as products, of which customers will like to check before making payment for a particular product. This necessitated for the preference of respondents to choose shopping online ahead of any other means. Lastly, respondents were ardent on choosing online shopping because of the availability of checking different kinds of products via the internet within a space of time. 


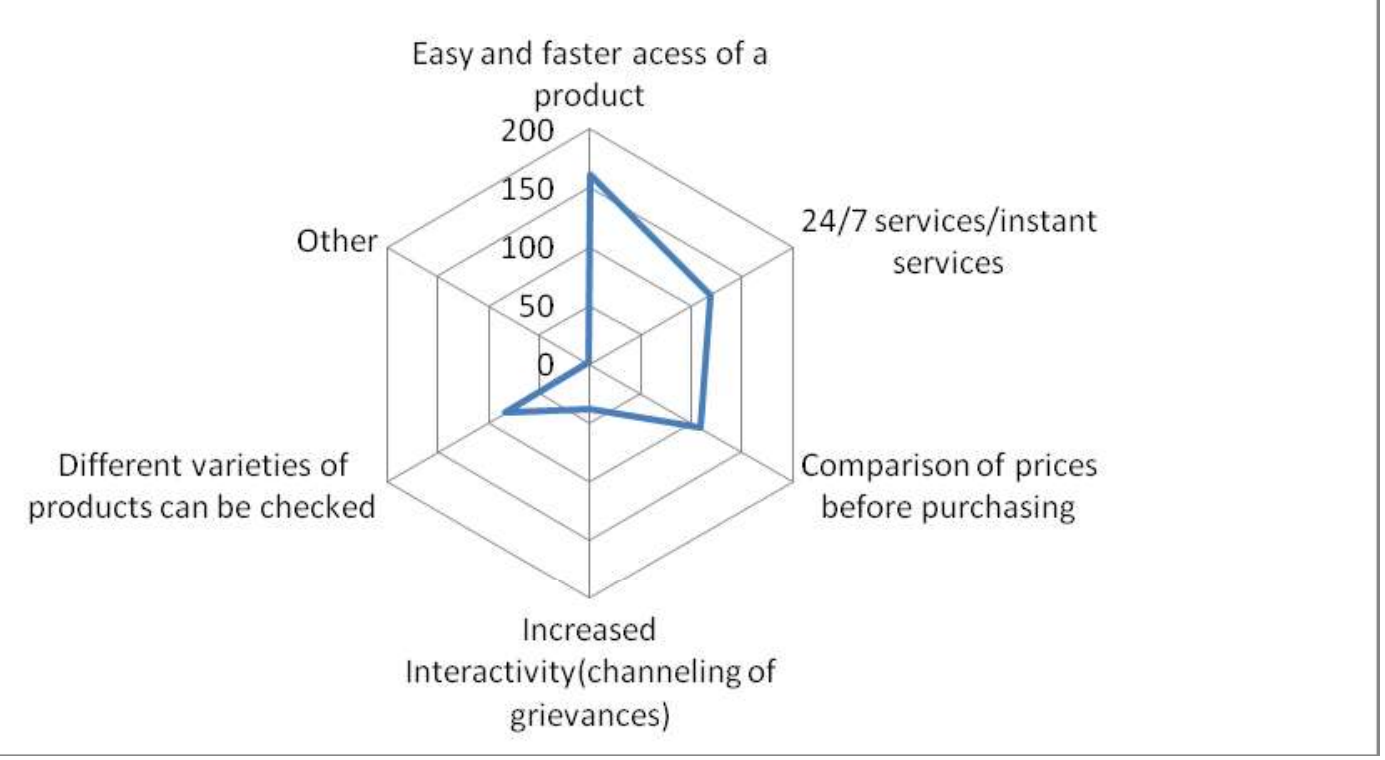

Figure 2: Customer preference for shopping through the internet.( Source Own survey)

\section{DISCUSSIONS AND CONCLUSIONS}

This study was conducted on the premise of demographic variables in a developing country pertaining to the current disposition of online shopping behavior of customers. In other words, how these demographic attributes negatively or positively affect the inclination of online shopping pattern of customers in a developing country. Three main constructs were focussed on for the study as independent variables, namely age, gender, and education with its corresponding dependent variable. The outcome of this research indicated that customer preference for online shopping in Ghana and for that matter developing economies is relatively lower compared to the conventional brick and mortar style of shopping for customers. The study also went on to analyze some possible reasons that might hinder or influence customer's predilection to embark on online shopping in this era of technological dispensation.

The results of our hypothesis (H1) confirmed that there is no significant association between age and gender on the rate at which customers make use of the internet in shopping. It can be concluded that our hypothesis (H1) were approved. From the onset of our research, it was ascertained that there is no relationship between age and gender on the frequency of how customers make use of the internet, that is whether daily, once per week, twice per month or any other means. However, our final evaluation indicates that indeed there is no association between the variables under study.

In terms of the channels consumers' use in checking the availability of products in the market with its corresponding demographic variables in a the study, our hypothesis $(\mathrm{H} 2)$ set prior to the study was disapproved. Thus, age and gender play an instrumental role in checking availability of new products, giving the channels under investigations, namely; online. Printed media, traditional and other means. It was disapproved that customers age and gender has a greater association with the aforementioned channels.

On the other hand, there was an entirely different result of our hypothesis (H3) regarding the support and advocacy of the general usage of internet for shopping. Surprisingly, age had a different result attesting to the fact that there is no association connecting the support of internet usage in Ghana. Hence, our hypothesis cannot be rejected signifying that the categories of age have no interrelationship between the support of online shopping. However, education with its investigative 
variables such as high school, bachelors or post graduate had a relationship with the support of internet usage for shopping. With this, our hypothesis that there is no relationship between education and the support of internet usage could be rejected hence there was a relationship.

\subsection{Recommendations and Future research}

This article has provided a vivid quantitative and theoretical overview which could possibly serve as a keynote to marketers in the international and local purview, in an attempt to channel their attention to the developing countries with fully established eCommerce and internet marketing ideologies. Moreover, this study has brought to the fore how demographic variables affect the relationship between online buying behavior of customers and intentions to purchase through online in a developing country.

Notwithstanding the valuable contribution of this study to existing knowlege,marketers should work harder to inform consumers about the convenience and ease to adapt the online buying phenomenon. This is evidenced from our results indicating that in spite of most respondent's been keen on their conventional way of shopping,yet most of the responses indicated their desire for online shopping.Therefore is feasible for marketers who are bent on entering the developing fold and for that matter the African continent and to be precise Ghana to create the awareness of online shopping.It is unarguably clear that any successful business is centered on the outcome of having a deeper understanding of consumer behaviour of its customers, that is, which factors influences their purchasing behaviour,including demographics.In the light of this, an indepth revelation of customers in a developing country notably Ghana can assist marketers who are bent on entering the market to be able to position themselves interms of segmentation of customers, creating effective customer relationships, enriching competitive positioning of the business, designing affable websites to attract the needed customers.

Again,in spite of the valuable contributions to academia and industry in general regarding the findings of online buying behavior in a developing country,the author is quick to point out one of the major limitations of the current study.The key limitation of the study is that the construct(demographics) for analyzing the propensity for online shopping with its limited study in particular the sub Saharan regions of Africa, in the developing country cannot be described as overly exhaustive, given the limited coverage of existing literature in the sphere of study.

On a final note, the next step in this particular study will be to consider an additional demographic variance using different algorithms in the evaluation coupled with a large sample size. On this note, the author recommends that interested scholars should channel their attention to the magnitude of online buying phenomenon in a developing country, specifically the African sub regions. Given the background that the internet has become part of us and is no longer leaving sooner or later.

\section{ACKNOWLEDGEMENT}

This paper presents the results of a project financed by the Internal Grant Agency (IGA): IGA/FaME/2016/006) Enterprises' Competitiveness Influenced by Consumer Behavior on Traditional and online markets. 


\section{REFERENCES}

Addinsoft (2014). XLSTAT 2014, Data analysis and statistics with Microsoft Excel, Paris, France Akhter, S.H., 2012. Who spends more online? The influence of time, usage variety, and privacy concern on online spending. Journal of Retailing and Consumer Services, 19(1), pp.109-115.

Alturkestani, H. (2004). E-marketing application on Saudi business sector. E-ommerce Symposium, 1, King Khaled University, Abha, Kingdom of Saudi Arabia, 257-265

Beldona, S., Racherla, P. and Mundhra, G.D., 2011. To buy or not to buy: Indian consumers' choice of online versus offline channels for air travel purchase. Journal of Hospitality Marketing \& Management, 20(8), pp.831-854.

Bouzaabia, O., Bouzaabia, R. and Capatina, A., 2016. Determinants of Internet Use by Senior Generation: A Cross Cultural Study. International Journal of Technology and Human Interaction (IJTHI), 12(1), pp.63-82.

Brashear, T.G., Kashyap, V., Musante, M.D. and Donthu, N., 2009. A profile of the Internet shopper: Evidence from six countries. Journal of Marketing Theory and Practice, 17(3), pp.267282.

Burke, R.R., 2002. Technology and the customer interface: what consumers want in the physical and virtual store. Journal of the academy of Marketing Science, 30(4), pp.411-432.

Chakraborty, R., Lee, J., Bagchi-Sen, S., Upadhyaya, S. and Rao, H.R., 2016. Online shopping intention in the context of data breach in online retail stores: An examination of older and younger adults. Decision Support Systems.

Chakraborty, R., Lee, J., Bagchi-Sen, S., Upadhyaya, S. and Rao, H.R., 2016. Online shopping intention in the context of data breach in online retail stores: An examination of older and younger adults. Decision Support Systems.

com/news/Online Shopping.shtml

Desai, K., Chewning, B. and Mott, D., 2015. Health care use amongst online buyers of medications and vitamins. Research in Social and Administrative Pharmacy, 11(6), pp.844-858.

Domina, T., Lee, S.E. and MacGillivray, M., 2012. Understanding factors affecting consumer intention to shop in a virtual world. Journal of retailing and consumer services, 19(6), pp.613-620.

Donthu, N. and Garcia, A., 1999. The internet shopper. Journal of advertising research, 39(3), pp.52-52.

Doolin, B., Dillons, S., Thompson, F. and Corner, J.L., 2007. Perceived risk, the Internet shopping experience and online purchasing behavior: A New Zealand perspective. Electronic commerce: Concepts, methodologies, tools, and applications, pp.324-345.

Fang, X. and Yen, D.C., 2006. Demographics and behavior of Internet users in China. Technology in Society, 28(3), pp.363-387.

Garbarino, E. and Strahilevitz, M., 2004. Gender differences in the perceived risk of buying online and the effects of receiving a site recommendation. Journal of Business Research, 57(7), pp.768775 . 
Hansen, T., 2005. Understanding consumer online grocery behavior: Results from a Swedish study. Journal of Euromarketing, 14(3), pp.31-58.

Hart, M., 2008, October. Do online buying behaviour and attitudes to web personalization vary by age group?. In Proceedings of the 2008 annual research conference of the South African Institute of Computer Scientists and Information Technologists on IT research in developing countries: riding the wave of technology (pp. 86-93). ACM.

Hou, J. and Elliott, K., 2014. How do online bidders differ from non-bidders?. Journal of Retailing and Consumer Services, 21(1), pp.18-25.

Internet Shoppers up 40\% in Two Years. Retrieved September 15, 2012 from http://nz.nielsen.

Kumar, A. and Dash, M.K., 2015. Effectiveness of electronic service dimensions on consumers' electronic buying behaviour and exploration of different groups. International Journal of Business Innovation and Research, 9(1), pp.81-99.

Li, N. and Zhang, P., 2002. Consumer online shopping attitudes and behavior: An assessment of research. AMCIS 2002 Proceedings, p.74.

Li, X., 2007. Agent-based consumer learning in e-commerce. International journal of networking and virtual organisations, 4(1), pp.65-75.

Lian, J.W. and Lin, T.M., 2008. Effects of consumer characteristics on their acceptance of online shopping: Comparisons among different product types. Computers in Human Behavior, 24(1), pp.48-65.

Lian, J.W. and Yen, D.C., 2014. Online shopping drivers and barriers for older adults: Age and gender differences. Computers in Human Behavior, 37, pp.133-143.

Liu, H., Sadygov, R.G. and Yates, J.R., 2004. A model for random sampling and estimation of relative protein abundance in shotgun proteomics. Analytical chemistry, 76(14), pp.4193-4201. Maceviciute, E., 2007. Review of: Pickard, Alison Jane. Research methods in information London: Facet Publishing, 2007.

Mohd Suki, N., Ramayah, T. and Mohd Suki, N., 2008. Internet shopping acceptance: Examining the influence of intrinsic versus extrinsic motivations. Direct Marketing: An International Journal, 2(2), pp.97-110.

Nabareseh, S., Osakwe, C.N., Klímek, P. and Chovancová, M., 2014. A comparative study of consumers' readiness for internet shopping in two African emerging economies: Some preliminary findings. Mediterranean Journal of Social Sciences.

Niu, H.J. and Chang, C.T., 2014. Addiction in cyberspace: flow experience on e-shopping. International Journal of Web Based Communities, 10(1), pp.52-68.

Panzone, L., Hilton, D., Sale, L. and Cohen, D., 2016. Socio-demographics, implicit attitudes, explicit attitudes, and sustainable consumption in supermarket shopping. Journal of Economic Psychology.

Quarshie, H.O. and Ami-Narh, J., 2012. The growth and usage of Internet in Ghana. Journal of Emerging Trends in Computing and Information Sciences, 3(9), pp.1302-1308. 
Quelch, J.A. and Klein, L.R., 1996. The Internet and international marketing. MIT Sloan Management Review, 37(3), p.60.

Richard, M.O., Chebat, J.C., Yang, Z. and Putrevu, S., 2010. A proposed model of online consumer behavior: Assessing the role of gender. Journal of Business Research, 63(9), pp.926-934.

Rigas, D. and Riaz, N., 2015. E-Commerce Purchase Intention in Emerging Markets: The Influence of Gender and Culture. In Cross-Cultural Design Applications in Mobile Interaction, Education, Health, Transport and Cultural Heritage (pp. 90-100). Springer International Publishing.

Román, S. and Riquelme, I.P., 2014. Personal Determinants Of Online Shopping Frustration And Its Influence On Consumers'positive Word Of Mouth. Journal of Electronic Commerce Research, 15(2), p.87.

Rose, S. and Dhandayudham, A., 2014. Towards an understanding of Internet-based problem shopping behaviour: The concept of online shopping addiction and its proposed predictors. Journal of behavioral addictions, 3(2), pp.83-89.

Sakalauskas, D.P. and Ibeh, K.I., 2005. Internet marketing and the realty sector: some crossnational insights from Canada and the UK. Journal of Euromarketing, 14(4), pp.53-76.

Saleh, M.A.H., Assessing the Consumers' Propensity for Online Shopping: A Demographic Perspective.

San Martín, S. and Jiménez, N.H., 2011. Online buying perceptions in Spain: can gender make a difference?. Electronic Markets, 21(4), pp.267-281.

Sharma, S. and Sitlani, M., 2013. Online Shopping Among Higher Education Students In Indore: A Factor Analysis Approach. Indian Journal of Marketing, 43(1), pp.44-53.

Shim, S. and Mahoney, M.Y., 1991. Electronic shoppers and nonshoppers among videotex users: Shopping orientations, videotex usages, and demographics. Journal of Direct Marketing, 5(3), pp.29-38.

Shuyang, C., Meng, S. and Haotong, L., 2014, October. The comparative study between China and South Korea on online shopping. In Management of e-Commerce and e-Government (ICMeCG), 2014 International Conference on (pp. 16-19). IEEE.

Soopramanien, D.G. and Robertson, A., 2007. Adoption and usage of online shopping: An empirical analysis of the characteristics of "buyers" "browsers" and "non-internet shoppers". Journal of Retailing and Consumer Services, 14(1), pp.73-82.

Swinyard, W.R. and Smith, S.M., 2003. Why people (don't) shop online: A lifestyle study of the internet consumer. Psychology \& marketing, 20(7), pp.567-597.

The Nielsen Company. (2015) Over 875 Million Consumers have Shopped Online - the Number of Village, S.K., No, P. and Park, R.G.I., 2015. A Study on user perception and awareness Related to online privacy during online Shopping. Journal of Theoretical and Applied Information Technology, 77(3). 
Xue-wu, S., Gui-hua, N. and Ling, S., 2006. Gender-based differences in the effect of web advertising in e-business. In 2006 International Conference on Management Science and Engineering. 